\section{Skrumping av atero- sklerotiske plakk}

Cyklodekstrin kan skrumpe aterosklerotiske plakk i mus. Kan det brukes i behandlingen av aterosklerose hos mennesker?

Kolesterolsenkende behandling med statiner gir ikke alltid tilfredsstillende resultat, og slett ikke på plakkene, der kolesterolkrystaller kan utløse en ugunstig inflammasjon. En studie viser at cyklodekstrin, som er tillatt brukt hos mennesker til å gjøre lipofile medikamenter vannløselige, har frapperende effekt i en musemodell (1).

Cyklodekstrin reduserte størrelse og grad av inflammasjon i aterosklerotiske plakk og økte omdanningen av kolesterol til et oksysterol, som er vannløselig. Oksysterol kan bl.a. diffundere ut av makrofagene som lagrer kolesterol, og via en reseptor (LXR) aktivere gener som styrer kolesteroltransport ut av cellene, og andre gener som hemmer immunresponser. Slike effekter ble også påvist $\mathrm{i}$ inkuberte biopsier fra plakk i humane halsarterier (1).

- Denne studien representerer en helt ny tenkning om mulig behandling av aterosklerose, sier Finn Olav Levy, som er professor i farmakologi ved Universitetet i Oslo.

- Det er veldig interessant at man har et medikament som allerede er vist å være trygt for bruk hos mennesker, og som ser ut til å kunne «rense» blodårene for fettavleiringer som er forstadier til aterosklerose. Hvis det viser seg at slik behandling også kan ha effekt hos pasienter med ateromatose, åpner dette for helt nye muligheter for behandling av hjerte- og karsykdom. Det må også avklares hvor tidlig i den aterosklerotiske prosessen slik behandling eventuelt må settes inn, sier han.

\section{Haakon B. Benestad}

Universitetet i Oslo

\section{Litteratur}

1. Zimmer S, Grebe A, Bakke SS et al. Cyclodextrin promotes atherosclerosis regression via macro phage reprogramming. Sci Transl Med 016; 8: 333 ra50.

\title{
Mobilapp kan bedre fødselsomsorg
}

\author{
En applikasjon til smarttelefoner bedrer ferdighetene til fødselshjelpere \\ i ressursfattige områder. Kanskje kan dette gi økt overlevelse blant \\ nyfødte?
}

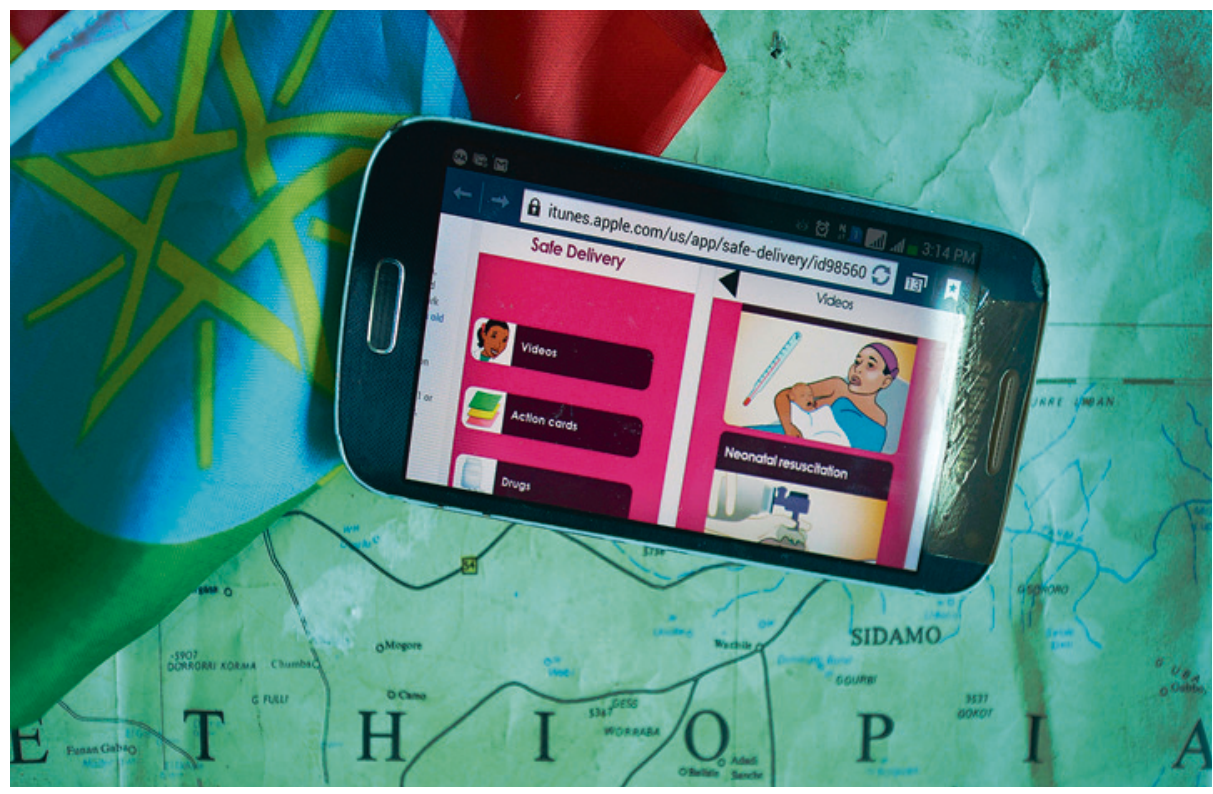

Illustrasjonsfoto: AFP/NTB scanpix

Mobiltelefonenes økende utbredelse, også i lavinntektsland, har åpnet muligheten for nye teknologiske, medisinske verktøy. Utallige applikasjoner til smarttelefoner er lagd med intensjon om å hjelpe klinikere i deres utdanning og praktisering, men få av disse applikasjonene har gjennomgått en vitenskapelig validering.

En dansk gruppe har utviklet en applikasjon som de kaller Safe Delivery App (SDA) (1), og effekten av å bruke den er blitt testet i en kontrollert, klyngerandomisert studie (2).

Applikasjonen omfatter instruksjonsvideoer og veiledning i fødselsomsorg. I studien ble 70 helsesentre i Etiopia randomisert, slik at halvparten av dem fikk utdelt smarttelefoner med applikasjonen til de ansatte. I løpet av 17 måneder i perioden 2013-15 fødte totalt rundt 3600 kvinner ved disse sentrene. Perinatal dødelighet ved helsesentrene som hadde fått applikasjonen, var 14 per 10000 fødsler versus 23 per 10000 fødsler ved de andre helsesentrene, men forskjellen var ikke statistisk signifikant (OR 0,76; 95\% KI 0,32-1,81).
Tester av helsearbeiderne viste imidlertid signifikant større fremgang i kunnskaper og ferdigheter hos dem som jobbet ved helsesentrene som hadde fått applikasjonen enn ved de andre helsesentrene.

Forfatterne konkluderer med at applikasjonen er effektiv for kvalitetsforbedring hos helsearbeidere, men at det trengs større studier for å kunne fastslå om bruk av applikasjonen også fører til økt overlevelse blant nyfødte i ressursfattige områder.

\section{Kristoffer Brodwall}

Institutt for global helse og samfunnsmedisin Universitetet i Bergen

\section{Litteratur}

1. Safe Delivery App. https://itunes.apple.com/us/ app/safe-delivery/id985603707? mt=8 (10.8.2016)

2. Lund S, Boas IM, Bedesa T et al. Association between the safe delivery app and quality of care and perinatal survival in Ethiopia: a randomized clinical trial. JAMA Pediatr 2016; 170: 765-71. 